\title{
MORPHOMETRIC CHANGES AND POST-PLANTING GROWTH AS A RESPONSE TO HARDENING ON Tabebuia roseo-alba SEEDLINGS
}

\author{
Danielle Acco Cadorin ${ }^{1 *}$; Ubirajara Contro Malavasi²; Marlene de Matos Malavasi ${ }^{3}$, João Alexandre Lopes \\ Dranski $^{4}$; Pablo Wenderson Ribeiro Coutinho ${ }^{5}$ \\ 1*Faculdade de Ensino Superior de São Miguel do Iguaçu, Departamento de Ciências Agrárias, São Miguel do Iguaçu, Paraná, Brasil - \\ danicadorin@gmail.com \\ ${ }^{2}$ Universidade Estadual do Oeste do Paraná, Programa de Pós-Graduação em Agronomomia, Marechal Cândido Rondon, Paraná, Brasil - \\ marlenemalavasi@yahoo.com.br \\ ${ }^{3}$ Universidade Estadual do Oeste do Paraná, Programa de Pós-Graduação em Agronomomia, Marechal Cândido Rondon, Paraná, Brasil - \\ biramalavasi@yahoo.com.br \\ ${ }^{4}$ Faculdade Educacional de Medianeira, Departamento de Agronomia, Medianeira, Paraná, Brasil - joaodranski@yahoo.com.br \\ ${ }^{5}$ Universidade Estadual do Oeste do Paraná, Programa de Pós-Graduação em Agronomomia, Marechal Cândido Rondon, Paraná, Brasil - \\ pablowenderson@hotmail.com
}

Received for publication: 10/06/2019 - Accepted for publication: 26/02/2021

\begin{abstract}
Resumo
Alterações morfométricas e crescimento pós-plantio em resposta a rustificação em mudas de Tabebuia roseoalba. O ensaio avaliou os efeitos de flexões caulinares e de ácido jasmônico nas características morfofisiológicas e no crescimento inicial de mudas de Tabebuia roseo-alba (Ridl). Sand. As mudas foram submetidas a 20 flexões caulinares diárias e aplicações semanais de $1 \mu \mathrm{mol} \mathrm{L}^{-1}$ de ácido jasmônico durante $4 \mathrm{e}$ 8 semanas. Mudas flexionadas diariamente por 8 semanas apresentaram redução no número de folhas, massa seca aérea e área foliar em relação aos demais tratamentos. Mudas controle externaram o maior extravasamento de eletrólitos do tecido radicular em relação às mudas rustificadas. Após plantio a campo, não foram detectadas diferenças nos incrementos em altura e diâmetro do caule ao nível do solo nas mudas submetidas aos diferentes tratamentos. Os métodos rustificativos testados não foram eficientes em melhorar o desempenho das mudas após o plantio.

Palavras-chave: ácido jasmônico, tigmomorfogênese, ipê-branco.
\end{abstract}

\begin{abstract}
The essay evaluated morphometric changes in response to stem bending and jasmonic acid on Tabebuia roseoalba (Ridl). Sand. seedlings. We tested 20 daily stem bendings and applications of $1 \mu \mathrm{mol} \mathrm{L}^{-1}$ of jasmonic acid for 4 or 8 weeks. Stem bending for 8 weeks resulted in seedlings with fewer leaves and smaller shoot dry biomass compared to seedlings subjected to the other treatments. The results of electrolyte leakage from root tissues of control seedlings showed higher value compared to results from seedlings subjected to the test treatments. After planting, we did not detect differences in height and diameter increments from seedlings subjected to the test treatments. Therefore, hardening methods did not improve post-planting seedling growth. Keywords: jasmonic acid, tigmomorphogenesis, ipê-branco.
\end{abstract}

\section{INTRODUCTION}

Tabebuia reseo-alba (Ridl). Sand., also known as ipê-branco or pau d'arco, belonging to the Bignoneaceae family, is a woody species native from the Brazilian flora, appearing predominantly in the Seasonal Moist Deciduous Tropical Forest. The species is described as deciduous that appears both in the old-growth forest as in second-growth formations. The species received an importance value of 3.26 as a fragment of the Seasonal Moist Deciduous Tropical Forest in the Pernambuco state (HOLANDA et al., 2010) and of 2.6 in the Seasonal Moist Deciduous Submontane Tropical Forest in the Mato Grosso do Sul state (URBANETZ et al., 2012), indicating its wide distribution and importance on that phytophysiognomy, which justifies the propagation of the species for conservation purposes.

Reforestation is carried out to minimize environmental impact caused by men, maintaining biodiversity, for which native woody species are the most effective on the revegetation of degraded and riparian areas (HEBERLE et al., 2018). The success of forest planting depends on several factors, among which the endurance of seedlings used on reforestation must be enough to withstand post-planting stress.

The development of the seedlings in the field is related to the quality attributes of such seedlings, which can be mainly assessed via their morphological and physiological characteristics (RITCHIE et al., 2010). Seedlings development in plant nurseries is one of the main steps to identify their survivability in the field, where the seedlings height is commonly used as a quality parameter for seedlings (AUCA et al., 2018; DIONÍSIO et al., 2019). Thus, it is possible to notice that the production of forest species is one of the main activities on reforestation, since the success of subsequent populations on the reforestation of degraded areas may be compromised. 
The initial seedlings growth combined with their quality are decisive factors on reforestation programs both for commercial and for degraded areas recovery purposes. Therefore, the knowledge of factors that positively affect the survivability and the initial development of seedlings under field conditions is important (DIONÍSIO et $a l ., 2019)$. Hence, the production of seedlings to be planted on proper areas or environments is an essential activity to analyze the survivability of the seedlings in the field, because when they do not present proper quality, they need increased initial protection and proper handling for the seedlings of woody species to survive in the field (HERBELE et al., 2018).

The use of mechanical stimulation and vegetal regulators cause morphophysiological changes during the production of seedlings (ORO et al., 2012; VOLKWEIS et al., 2014; HEBERLE et al., 2018) that might or might not contribute with higher post-planting survivability and growth. The objective of this work is to evaluate the effects of the hardening methods of stem bending and jasmonic acid on the post-planting morphophysiological changes and growth of $T$. roseo-alba seedlings.

\section{MATERIAL AND METHODS}

Seeds of T.roseo-alba were collected in October, 2014, at three matrices located at the Entre Rios do Oeste do Paraná city, and planted, in November, 2014, in tubes with $120 \mathrm{~cm}^{3}$ filled with a commercial substrate with controlled-release fertilizer $\left(18 \mathrm{~N}-6 \mathrm{P}_{2} \mathrm{O}_{5}-10 \mathrm{~K}_{2} \mathrm{O}\right)$ added on the proportion of $3.0 \mathrm{~kg} \mathrm{~m}^{-3}$ of substrate.

The tubes were placed on plastic holders with capacity for 96 tubes and stored on a non-acclimatized protected environment covered by a low-density and anti-UV $150 \mu \mathrm{m}$-thick polyethylene screen, resulting on $20 \%$ shading. Such storage is located at the Universidade Estadual do Oeste do Paraná at the coordinates $24^{\circ}$ 55' 83" $\mathrm{S}$ and $54^{\circ} 04^{\prime} 56^{\prime \prime} \mathrm{W}$. The local climate, according to Köppen, is characterized as humid subtropical (Cfa), with average temperature on the coldest month inferior to $18{ }^{\circ} \mathrm{C}$ and average temperature on the hottest month above $22{ }^{\circ} \mathrm{C}$, with infrequent frosts and tendency for rain concentration on the summer months, however, with no welldefined dry season.

The application of the treatments started 130 days after the seedlings emerged. At that point in time, the seedlings had average height of $11.7 \mathrm{~cm}$ and stem diameter of $3.89 \mathrm{~mm}$. The experimental design during the plant nursery phase was random blocks with five treatments, five repetitions of sixteen seedlings that were subject to: (TEST) - witness with deionized water + non-ionic surfactant applied weekly; (TIG4) - 20 daily bendings for 4 weeks + deionized water and non-ionic surfactant applied weekly; (TIG8) - 20 daily bendings for 8 weeks + deionized water and non-ionic surfactant applied weekly; (JA4) - $1 \mu \mathrm{mol} \mathrm{L} \mathrm{L}^{-1}$ of jasmonic acid + deionized water + non-ionic surfactant applied weekly for 4 weeks; (JA8) - $1 \mu \mathrm{mol} \mathrm{L}^{-1}$ of jasmonic acid + deionized water + nonionic surfactant applied weekly for 8 weeks.

Both on the seedlings formation and on the period of study, the plants were irrigated by spraying twice a day with a $10 \mathrm{~mm}$ water sheet. The stem bendings were performed by daily mechanical stimulation using a oneway pass of a structure comprising a horizontal PVC pipe with diameter of $25 \mathrm{~mm}$ attached to a metal frame with ball bearings. The seedlings were bended vertically at most $45^{\circ}$ by the PVC pipe on the lower third of the leaves (Figure 1), always at the same time of the day, at a speed of $0.10 \mathrm{~m} / \mathrm{sec}$ (VOLKWEIS et al., 2014).

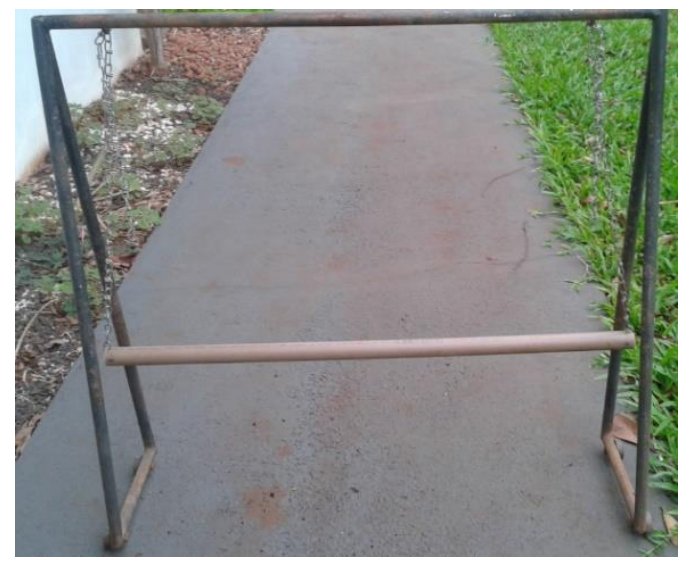

Figure 1 - Structure of the equipment used for mechanical rusting of ipê-braco (Tabebuia roseo-alba) seedlings.

Figura 1 - Estrutura do equipamento utilizado para rustificação mecânica das mudas de ipê-branco (Tabebuia roseo-alba). 
The usage of the growth regulator was performed once a week via spraying the leaves with jasmonic acid at the concentration of $1 \mu \mathrm{mol} \mathrm{L} \mathrm{L}^{-1}$, with a volume of $6 \mathrm{~mL}$ per seedling, point at which the liquid started dropping from the leaves. The solutions comprised jasmonic acid, deionized water, and non-ionic surfactant, deployed with a manual backpack sprayer.

At the end of the experiment period, twelve seedlings were taken at random for the determination of the number of leaves, of the seedling height increment, and of the stem diameter and of the ratio between the height and the stem diameter (robustness index).

In addition, four seedlings were selected at random for the determination of the root dry mass and of the shoot dry mass, of the Dickson quality index, of the leaves area, of the root tissue electrolyte leakage, and of the chlorophyll pigment content. The masses of the root dry matter and of the leaves tissues were obtained via drying in an air circulation greenhouse at $65^{\circ} \mathrm{C}$ for 72 hours. The root tissue electrolyte leakage test was performed according to the methodology proposed by Wilner (1960). The leaves area was determined by the leaf disc method and the Dickson quality index, according to Dickson et al. (1960).

Four seedlings were randomly picked and used for the determination of the root potential growth. The seedlings were planted at the end of the treatment in nursery pots with $3.4 \mathrm{dm}^{3}$ filled with sand. The seedlings were kept in the pots for 28 days, being irrigated daily. After such period, the dry matter mass of new roots that emerged from the clod was measured (RITCHIE et al., 2010).

The concentrations of chlorophyll $a$, chlorophyll $b$, and chlorophyll $a+b$ were determined via the methodology proposed by Barbieri Junior et al. (2010), with the suppression of the grinding and centrifugation. Four leaf samples with $3 \mathrm{~cm}^{2}$ were used, randomly picked, adding up to $12 \mathrm{~cm}^{2}$ stored for 48 hours in $10 \mathrm{~mL}$ of $80 \%$ acetone at $25^{\circ} \mathrm{C}$. After such period, $3 \mathrm{~mL}$ parts were taken for the deriving of their absorbance values at the wavelengths of 645 and $663 \mathrm{~nm}$ using a spectrophotometer — values expressed in $\mu \mathrm{mol} \mathrm{m}{ }^{-2}$.

One week after the application of the treatments, four seedlings were planted in the field, also by random block alignment. Planting took place in July, 2015, in an area of the Marechal Cândido Rondon city, state of Paraná. The climate data were obtained from the automatic surface observation meteorological station on the vicinities of the experimental area.

The local soil is categorized as eutroferric Red Latosol and presented the following characteristics at the 0-20 layer: Mo: $130.0 \mathrm{~g} \mathrm{dm}^{-3}, \mathrm{P}$ (Mehlich): $3.28 \mathrm{mg} \mathrm{dm}^{-3}, \mathrm{~K}$ (Mehlich): $0.50 \mathrm{cmol}_{\mathrm{c}} \mathrm{dm}^{-3}, \mathrm{phCaCl}_{2}: 5.7, \mathrm{H}+\mathrm{Al}: 2.26$ $\mathrm{cmol}_{\mathrm{c}} \mathrm{dm}^{-3}$, Ca: $4.6 \mathrm{cmol}_{\mathrm{c}} \mathrm{dm}^{-3}, \mathrm{Mg}: 2.10 \mathrm{cmol}_{\mathrm{c}} \mathrm{dm}^{-3}, \mathrm{SB}: 7.2 \mathrm{cmol}_{\mathrm{c}} \mathrm{dm}^{-3}$, and V: $76.11 \%$. Holes with diameter of $27 \mathrm{~cm}$ and depth of $50 \mathrm{~cm}$, each row being 3 meters apart from each other and each plant being 1 meter apart from each other were used for planting. The applied cultural methods were mowing and manual removal of weeds when necessary.

At 90, 180, 270, and 360 days after planting, the percentage of survival and the height and stem diameter at ground level were evaluated for the surviving seedlings. On the evaluation of the increments on the field, the data were analyzed on split-plot visualizations over time, covering the five treatments at the whole plot unit and the four evaluation periods at the subplot experimental unit.

To evaluate the variance analysis (ANOVA), the data were first verified according to: a) normality with the Shapiro-Wilk test $(p>0.05)$, b) homoscedasticity via the Bartlett test $(p>0.05)$. Once these premises have been fulfilled, the data were submitted to the variance analysis, and, if significant differences were detected in the data, the averages were compared using the Tukey test $(p<0.05)$ via the SISVAR statistics software (FERREIRA, 2013). Since the data did not present residual distribution normality, the survival in the field data were submitted to the Friedman test.

\section{RESULTS}

There were no differences $(\mathrm{P}>0.05)$ on the height increase $(0.16 \pm 0.02 \mathrm{~cm})$, on the robustness index $(2.66 \pm 0.04)$, on the root dry mass $(1.324 \pm 68 \mathrm{mg})$, and on the root growth potential $(3.74 \pm 1.1 \mathrm{mg}) \mathrm{measured}$ and calculated on seedlings submitted to the treatments. The increase on the stem diameter was significantly larger on seedlings pulverized with jasmonic acid during 8 weeks when compared to the control treatment and to the ones submitted to stem bending for the same period (Table 1).

On all hardening treatments, the root tissue electrolyte leakage was significantly lower when compared to the witness. The application of stem bending for 8 weeks reduced the number of leaves, the leaf area, and the shoot dry matter when compared to the remaining treatments (Table 1). The Dickson quality index was reduced when 20 daily bendings for 8 weeks were used when compared to 20 daily bendings for 4 weeks.

Table 1 - Seedlings height increase (IH), stem diameter increment (ID), number of leaves (NF), leaf area (AF), robustness index (IR), shoot dry mass (MSA), root dry mass (MSR), Dickson quality index (IQD), and root electrolyte leakage (PER) on Tabebuia roseo-alba seedlings submitted to mechanical stimuli and jasmonic acid applications.

FLORESTA, Curitiba, PR, v. 51, n. 3, p. 539-546, jul/set 2021.

Cadorin, D. A. et.al.

ISSN eletrônico 1982-4688

DOI: $10.5380 /$ rf.v51 i3. 65358 
Tabela 1 - Incremento de altura de mudas (IH), incremento no diâmetro do coleto (ID), número de folhas (NF), área foliar (AF), índice de robustez (IR), massa seca aérea (MSA), massa seca radicular (MSR), índice de qualidade de Dickson (IQD), potencial de crescimento de raízes (PCR) e perda de eletrólitos de raízes (PER) em mudas de Tabebuia roseo-alba submetidas a estímulos mecânicos e aplicações de ácido jasmônico.

\begin{tabular}{|c|c|c|c|c|c|c|c|c|c|c|}
\hline \multirow[b]{2}{*}{ Treatment } & $\mathrm{IH}$ & ID & $\mathrm{NF}$ & $\mathrm{AF}$ & IR & MSA & MSR & IQD & PCR & PER \\
\hline & $\begin{array}{l}\mathrm{cm} / \\
\text { plant }\end{array}$ & $\begin{array}{l}\mathrm{mm} / \\
\text { plant }\end{array}$ & \multicolumn{2}{|c|}{$\mathrm{cm}^{2} /$ plant } & \multicolumn{4}{|c|}{$\mathrm{mg} /$ plant } & & $\%$ \\
\hline TEST & 0.23 & $\begin{array}{c}0.17 \\
b^{*}\end{array}$ & $4.33 \mathrm{a}$ & $65.35 \mathrm{a}$ & 2.69 & $799.11 \mathrm{a}$ & $1.35 \mathrm{a}$ & $1.47 \mathrm{a}$ & 2.00 & $28.12 \mathrm{a}$ \\
\hline TIG4 & 0.24 & $0.23 \mathrm{ab}$ & $2.83 \mathrm{~b}$ & $36.81 \mathrm{~b}$ & 2.63 & $637.31 \mathrm{a}$ & $1.21 \mathrm{a}$ & $1.22 \mathrm{ab}$ & 0.12 & $20.57 \mathrm{~b}$ \\
\hline TIG8 & 0.11 & $0.16 \mathrm{~b}$ & $1.54 \mathrm{c}$ & $15.16 \mathrm{c}$ & 2.73 & $387.88 \mathrm{~b}$ & $1.10 \mathrm{a}$ & $1.03 \mathrm{~b}$ & 0.37 & $20.48 \mathrm{~b}$ \\
\hline JA4 & 0.10 & $0.21 \mathrm{ab}$ & $4.28 \mathrm{a}$ & $\begin{array}{c}50.76 \\
\mathrm{ab}\end{array}$ & 2.67 & $774.71 \mathrm{a}$ & $1.43 \mathrm{a}$ & $1.37 \mathrm{a}$ & 8.45 & $21.19 \mathrm{~b}$ \\
\hline JA8 & 0.13 & $0.28 \mathrm{a}$ & $4.01 \mathrm{a}$ & $63.94 \mathrm{a}$ & 2.61 & $824.40 \mathrm{a}$ & $1.53 \mathrm{a}$ & $1.42 \mathrm{a}$ & 7.74 & $18.92 \mathrm{~b}$ \\
\hline $\mathrm{CV}(\%)$ & 43.00 & 27.43 & 12.99 & 19.72 & 5.97 & 13.25 & 15.76 & 10.28 & 123 & 18.78 \\
\hline
\end{tabular}

*Averages followed by the same lowercase letter at the columns do not differ statistically among themselves by the Tukey test at a $5 \%$ error probability.

TEST $=$ Witness; TIG4 = Stem bending for 4 weeks; TIG8 = Stem bending for 8 weeks; JA4 = jasmonic acid applications for four weeks; JA8 = jasmonic acida applications for 8 weeks.

Chlorophyll $a, b$, and total chlorophyll also presented differences between the control seedlings and those pulverized with jasmonic acid and stimulated by stem bending (Table 2). Reduction on the chlorophyll $a$ was observed even when jasmonic acid and stem bending were applied during eight weeks. Regarding chlorophyll $b$, the same treatments that resulted in the lower concentrations of chlorophyll $a$ also presented the lowest levels of chlorophyll $b$, where the treatment that used stem bending for eight weeks was the one that statistically presented the lowest concentrations, which might interfere with the physiological performance of the seedlings.

Table 2 - Chlorophyll $a$, Chlorophyll $b$, and Chlorophyll $a+b$ for Tabebuia roseo-alba seedlings submitted to mechanical stimuli and jasmonic acid applications.

Tabela 2 - Clorofila $a$, clorofila $b$ e clorofila $a+b$ em mudas de Tabebuia roseo-alba submetidas a estímulos mecânicos e aplicações de ácido jasmônico.

\begin{tabular}{cccc}
\hline \multirow{2}{*}{ Treatment } & Chlorophyll $a$ & Chlorophyll $b$ & Chlorophyll $a+b$ \\
\cline { 2 - 4 } & & $\mu$ mol m${ }^{-2}$ \\
\hline TEST & $214.38 \mathrm{a}^{*}$ & $84.98 \mathrm{a}$ & $299.37 \mathrm{a}$ \\
TIG4 & $174.61 \mathrm{ab}$ & $80.25 \mathrm{a}$ & $254.86 \mathrm{ab}$ \\
TIG8 & $101.95 \mathrm{c}$ & $48.64 \mathrm{~b}$ & $150.60 \mathrm{c}$ \\
JA4 & $145.14 \mathrm{bc}$ & $66.57 \mathrm{ab}$ & $211.71 \mathrm{bc}$ \\
JA8 & $155.27 \mathrm{bc}$ & $74.47 \mathrm{ab}$ & $229.74 \mathrm{abc}$ \\
\hline CV(\%) & 15.25 & 16.67 & 15.63 \\
\hline
\end{tabular}

*Averages followed by the same lowercase letter at the columns do not differ statistically among themselves by the Tukey test at a $5 \%$ error probability.

TEST $=$ Witness; TIG4 = Stem bending for 4 weeks; TIG8 = Stem bending for 8 weeks; JA4 = jasmonic acid applications for four weeks; JA8 = jasmonic acida applications for 8 weeks.

The total chlorophyll content presented an unexpected result for the use of jasmonic acid, since its application for eight weeks presented the highest concentration of the photosynthesizing pigments when compared to the treatments that featured stem bending for four weeks and the witness (Table 2).

On the field experiment, there was no interaction between the hardening treatments and the seedlings evaluation periods. The hardening treatments applied at the plant nursery phase did not result in increment differences on the height and on the stem diameter at the soil level after planting, and there was no influence on seedlings survival (95\%) 360 days after planting.

Table 3 - Increment in height (IH) and in stem diameter (ID) on T.roseo-alba seedlings at 90, 180, 270, and 360 days after planting. 
Tabela 3 - Incremento na altura (IH) e no diâmetro do colo ao nível do solo (ID) em mudas de T.roseo-alba aos 90, 180, 270 e 360 dias após o plantio.

\begin{tabular}{ccc}
\hline \multirow{2}{*}{ Evaluations } & $\mathrm{IH}$ & $\mathrm{ID}$ \\
\cline { 2 - 3 } & $\mathrm{cm} /$ plant & $\mathrm{mm} / \mathrm{plant}$ \\
\hline 90 days & $9.52 \mathrm{c}^{*}$ & $1.06 \mathrm{c}$ \\
180 days & $28.85 \mathrm{~b}$ & $5.14 \mathrm{~b}$ \\
270 days & $50.81 \mathrm{a}$ & $8.82 \mathrm{a}$ \\
360 days & $9.04 \mathrm{c}$ & $1.97 \mathrm{c}$ \\
\hline $\mathrm{CV}(\%)$ & 23.95 & 28.00
\end{tabular}

*Averages followed by the same lowercase letter at the columns do not differ statistically among themselves by the Tukey test at a $5 \%$ error probability.

This evaluation during the execution of the study of height and stem diameter at soil level corresponds to the increments that took place on the third trimester of the experiment, namely January, February, and March. Probably the highest increment on such trimester is due to the climatic conditions. The solar radiation and temperature averages were the highest on the third evaluation period $\left(18.78 \mathrm{Mi} \mathrm{m}^{-2}\right.$ and $\left.25^{\circ} \mathrm{C}\right)$ when compared to the other trimesters and there were no severe drought periods, which is probably related to the photosynthetic activity and consequent seedlings growth, even though the simple correlation indicated meaningful relation between the height increment and the solar radiation.

\section{DISCUSSION}

Factors such as species and growth stage might change the behavior of seedlings in response to hardening treatments. For instance, Oro et al. (2012) did not find increment differences on height and stem diameter on Cariniana estrellensis (Raddi) Kuntze seedlings treated or not with ethephon. Dranski et al. (2013) verified a reduction of $50 \%$ on the height increment and an increase of $44 \%$ on the stem diameter increment on Pachystroma longifolium (Ness) I. M. Johnst. seedlings pulverized with $600 \mathrm{mg} \mathrm{L}^{-1}$ of ethephon when compared to the control treatment. This proves that the hardening method behaves differently for each species and growth phase of the seedling, showing that these are decisive factors for the establishment of the plant and its survival on the field.

The increase on the stem diameter is a desired change after the seedling hardening. Ritchie et al. (2010) pointed out that such variable is a good non-destructive predictor of the seedlings development post-planting.

Often, responses to mechanical stimulation include reduction of the cellular elongation with subsequent reduction of the height increments on several species, also presenting secondary growth stimulation with subsequent increase on the stem diameter on some plants (DRANSKI et al., 2013; VOLKWEIS et al., 2014; CADORIN et al., 2015). Such behavior was not observed in this study, where the mechanical stimulation did not yield morphometric changes on T.roseo-alba seedlings.

Herbele et al. (2018), by applying jasmonic acid to ipê-roxo (Handroanthus impetiginosus Mart. ex DC. Mattos) and guajuvira (Patagonula americana L.) seedlings, verified that the concentration of this plant regulator is different for yielding good seedlings for each species. The indicated concentrations of jasmonic acid, according to the study conditions, is $1.5 \mu \mathrm{mol} \mathrm{L}-1$ for ipê-roxo and $1.0 \mu \mathrm{mol} \mathrm{L}^{-1}$ for guajuvira in order for these seedlings to present initial development gains on the field.

The stem diameter increase observed on seedlings treated with jasmonic acid might be related to the ethylene synthesis. The exogenous application of jasmonates can increment the biosynthesis of the hormone due to the synthase or oxidase of 1-aminocyclopropane-1-carboxylic acid (VIEIRA et al., 2010). The acid synthase is the catalyst enzyme of the $S$-Adenosyl methionine into the acid and its level can be regulated by several internal and environmental factors. The acid oxidase catalyzes the conversion of the acid into ethylene at the last phase of the hormone synthesis (TAIZ; ZEIGER, 2017).

The jasmonic acid level on plants varies as a function of the tissue, the type of cell, the development phase, and the response to several environmental stimula (HUANG et al., 2017). Methyl jasmonate can also act as a prevention to insects' attacks, since Zas et al. (2014) observed in their study a reduction on the attacks by Hylobius abietis on pinus seedlings planted in Spain and in Sweeden.

Ethylene is the responsible for several behaviors on the plants development and among its effects is the lateral expansion of cells. Ethylene modifies the orientation of the cellulose microfibrils at the cell membrane by changing the microtubules orientation, resulting in the lateral expansion instead of elongation (TAIZ; ZEIGER, 2017).

The application of ethylene on Cariniana estrellensis seedlings resulted in less electrolyte losses for seedlings treated with 100,200 , and $300 \mathrm{mg} \mathrm{L}^{-1}$ of the plant regulator when compared to the control treatment

FLORESTA, Curitiba, PR, v. 51, n. 3, p. 539-546, jul/set 2021.

Cadorin, D. A. et.al.

ISSN eletrônico 1982-4688

DOI: $10.5380 /$ rf.v51 i3. 65358 
(ORO et al., 2012). For seedlings of Maytenus ilicifolia (Schrad.) Planch, Volkweis et al. (2014) observed a linear reduction of the electrolyte losses on roots with increasing application $(0,5,10,20$, and 40 repetitions) of stem bending for 30 days. Clarke et al. (2009) reported that the application of $5 \mu \mathrm{mol} \mathrm{L}^{-1}$ of Methyl jasmonate on Arabidopsis thaliana L. reduced the leakage of electrolytes from the leaves on thermically stressed plants.

According to Kubis et al. (2014), the polyamines might be part of the plants mechanism to adapt to several kinds of environmental stress. The authors treated Cucumis sativus cv. Dar seedlings submitted to water restrictions with polyamines and found a reduction of up to $20 \%$ of the electrolytes leakage on roots when compared to untreated seedlings. According to the authors, the accumulation of polyamines and prolines on plants contributes to the protein, enzyme, and cell membrane integrity on plants submitted to stress via the osmotic adjustment, an effective mechanism for maintaining the cell turgidity.

Seedlings submitted to stem bending and jasmonic acid presented less ions leakage, indicating higher membrane integrity of roots featuring a diameter smaller than $2 \mathrm{~mm}$. From the previous result, it can be inferred that seedlings hardened via different methods have higher resistance to post-planting stress, keeping the membrane integrity of the thinnest roots.

Similar to the response to the application of jasmonates, the effects of stem bending seem to be related with the synthesis of ethylene. Biro and Jaffe (1984) state that mechanical stimuli, either in by attrition or in the form of a wound, induced the synthesis of ethylene in internodes of Phaseolus vulgaris L. cv. Cherokee Wax. Ethylene acts as the main regulator for the leaf abscission process (TAIZ; ZEIGER, 2017) and the application of the regulator yielded the reduction of the leaf area on Cariniana estrellensis seedlings, which was related by the authors to the reduction in the number of leaves (ORO et al., 2012).

Thus, reductions on the leaf area per plant and on the shoot dry area on seedlings bended for 8 weeks are probably effects of the leaf abscission, since there was a reduction on the total chlorophyll on plants bended for eight weeks and also on plants pulverized with jasmonic acid (Table 2), without, however, reducing the shoot dry mass of the latter (Table 1), making possible the inference that there was no reduction on the photosynthetic efficiency of the plants.

According to Vieira et al. (2010), the exogenous application of jasmonates cause effects associated with the senescence process of plants, among which is the chlorophyll degradation. According to the study by Zhu $e t$ al. (2015) performed with Arabidopsis thaliana L., to cause degradation, chlorophyll $b$ needs to be reduced to chlorophyll $a$ via the action of chlorophyllase $b$ reductase. The degradation of chlorophyll $a$ takes place through the action of the phaeophorbide $a$ oxygenase (PAO) and the red chlorophyll catabolite reductase (RCCR). In that study, the authors pointed out that the jasmonates activate the action of catabolic genes of chlorophyll responsible by the transcription of the PAO.

The reduction of the contents of chlorophyll $a$ and chlorophyll $a+b$ observed on the treatments featuring the application of jasmonic acid were probably not intense to the point of negatively interfering on the photophosphorylation on ipê-branco seedlings since there was no reduction on the shoot dry mass and on the leaf area of seedlings (Table 1). This reduction of the photosynthesizing pigments was reported by Anjum et al. (2011) for Glycine max L. Merrill plants when jasmonic acid was applied.

Chlorophylls are pigments responsible for the conversion of light radiation to energy under the form of ATP and NADPH. Hence, these photosynthesizable pigments are related to the $\mathrm{CO}_{2}$ net assimilation rate. It is important to highlight that both chlorophylls have different roles on the plant metabolism - chlorophyll $a$ is a very important pigment to the plant because it appears on the photochemical phase; but chlorophyll $b$ is an accessory pigment that, along with the carotenoids, aids the photoprotection of chlorophyll $a$, maximizing the energy absorption that effectively acts on photochemical reactions (COUTINHO et al., 2020). The amounts of chlorophyll $a$ and $b$ are found in different proportions, which occurs because the chlorophyll $a$ and $b$ proportion is $3: 1$, as a rule, but it varies according to the plant species, age of the leaf, the leaf position, and the plant crown (TAIZ; ZEIGER, 2017).

Cadorin et al. (2015) observed the best performance 180 days after the planting of Cordia trichotoma (Vell.) Arrab. Ex Steud seedlings submitted to 20 daily stem bendings and weekly applications of Methyl jasmonate for eight weeks when compared to the control seedlings. Dranski et al. (2015) reported higher stem diameter increments and stem volume on Pinus taeda L. seedlings bended daily 10 to 20 times for 60 days when compared to unbended seedlings at 90 days after planting.

The low mortality $(5 \%)$ and the lack of differences between the post-planting treatments might indicate the lack of enough adverse soil and climatic conditions. The performance of seedlings with different characteristics on different planting periods and conditions present differences on their production performance when hardened, being more pronounced for more stressful environmental conditions. Also, the indication of the species T.roseaalba for the recovery of degraded areas and its adaptability to dry and rocky areas show that this species already presents some hardness and, thus, it justifies the fact that even unhardened seedlings have shown good postplanting performance.

FLORESTA, Curitiba, PR, v. 51, n. 3, p. 539-546, jul/set 2021.

Cadorin, D. A. et.al.

ISSN eletrônico 1982-4688 
The concept of seedlings quality is not absolute and differs between species and planting sites. Height and stem diameter at the soil level increments were highlighted among the different evaluation periods. The highest increments were observed for 270 days in the field (Table 3).

\section{CONCLUSIONS}

- T.roseo-alba seedlings treated with jasmonic acid presented larger stem diameter when compared to the control seedlings.

- The electrolytes leakage at the root tissue was higher for control seedlings.

- The hardening treatments resulted in chlorophyll degradation.

- $\quad$ Seedlings bended for eight weeks presented decreased leaf area and shoot dry mass.

- Stem bending and jasmonic acid application at the doses and periods tested did not influence the survivability and growth of T.roseo-alba seedlings after planting.

\section{REFERENCES}

ANJUM, S. A.; XIE, X.; FAROOQ, M.; WANG, L.; XUE, L.; SHAHBAZ, M.; SALHAB, J. Effect of exogenous methyl jasmonate on growth, gás exchange and chlorophyll contents of soybean subjected to drought. African Journal of Biotechnology, Africa, v. 10, n. 47, p. 9640-9646, 2011.

AUCA, E. C.; DIONISIO, L. F. S.; BARDALES-LOZANO, R. M.; SCHWARTZ, G. Propagation of Brazil nut (Humb. y Bonpl) seedlings using seeds in mini-greenhouses. Revista Agro@mbiente On-line, Roraima, v. 12, n. 4, p. 300-313, 2018.

BARBIERI JUNIOR, A.; ROSSIELLO, R. O. P.; MORENZ, M. J. F.; RIBEIRO, R. C. Comparação de métodos diretos de extração e quantificação dos teores de clorofilas em folhas do capim-Tifton 85. Ciência Rural, Santa Maria, v. 40, n. 3, p. 633-636, 2010.

BIRO, R.; JAFFE, M. J. Thigmomorphogensis: ethylene evolution and its role in the changes observed in mechanically perturbed bean plants. Physiologia Plantarum, Sweden, v. 62, n. 2, p. 289-296, 1984.

CADORIN, D. A.; MALAVASI, U. C.; COUTINHO, P. W. R.; DRANSKI, J. A. L.; MALAVASI, M. M. Metil jasmonato e flexões caulinares na rustificação e crescimento inicial de mudas de Cordia trichotoma. Cerne, Lavras, v. 21, n. 4, p. 657-664, 2015.

CLARKE, S. H.; CRISTESCU, S. M.; MIERSCH, O.; HARREN, F. J. M.; WASTWRNACK, C.; MUR, L. A. J. Jasmonates act with salicylic acid to confer basal thermotolerance in Arabidopsis thaliana. New Phytologist, Reino Unido, v. 182, p. 175-187, 2009.

COUTINHO, P. W. R.; ECHER, M. M.; GUIMARÃES, V. F.; CARMO LANA, M.; INAGAKI, A. M.; BRITO, T. S.; ALVES, T. N. Photosynthetic efficiency of tomato plants submitted to calcium silicate application. Journal of Neotropical Agriculture, Cassilândia, v. 7 n. 4, p. 49-58, 2020.

DICKSON, A.; LEAF, A. L.; HOSNER, J. F. Quality appraisal of white spruce and white pine seedling stock in nurseries. The Forestry Chronicle, Canada, v. 1, p. 10-13, 1960.

DIONÍSIO, L. F. S.; AUCA, E. C.; SCHWARTZ, G.; BARDALES-LOZANO, R. M.; AGURTO, J. J. M.; CORVERA-GOMRINGER, R. Seedling production of Bertholletia excelsa in response to seed origin and position inside fruit. Forest Sciences, Columbia, v. 14, n. 3, p. 1-9, 2019.

DRANSKI, J. A. L.; MALAVASI, U. C.; MALAVASI, M. M. Relationship between lignin content and quality of Pinus taeda seedlings. Revista Árvore, Viçosa, v. 39, n. 5, p. 905-913, 2015.

DRANSKI, J. A. L.; MALAVASI, U. C.; MALAVASI, M. M.; JACOBS, D. F. Effect of ethephon on hardening of Pachystroma longifolium seedlings. Revista Árvore, Viçosa, v. 37, n. 3, p. 401-407, 2013.

FERREIRA, D. F. Sisvar: a guide for its bootstrap procedures in multiple comparisons. Ciência e Agrotecnologia, Lavras, v. 38, n. 2, p. 109-112, 2014.

HEBERLE, K.; DRANSKI, J. A. L.; MATOS MALAVASI, M.; MALAVASI, U. C. Morfometria e lignificação em função da aplicação de ácido jasmônico em mudas de ipê roxo e guajuvira. Scientia Agraria Paranaensis, Marechal Cândido Rondon, v. 17, n. 3, p. 317-325, 2018. 
HOLANDA, A. C.; PESSOA, M. M. L.; MELO, C. L. S. M.; SANTOS, M. S.; MARANGON, L. C.; FELICIANO, A. L. P. Estrutura de espécies arbóreas sob efeito de borda em um fragmento de floresta estacional semidecidual em Pernambuco. Revista Árvore, Viçosa, v. 34, n. 1, p. 103-114, 2010.

HUANG, H. B.; LIANGYU, L.; SUSHENG, S. Jasmonate action in plant growth and development. Journal of Experimental Botany, Barcelona, v. 68, n. 6, p. 1349-1359, 2017.

KUBIS, J.; FLORYSZAK-WIECZOREK, J.; Arasimowicz-Jelonek, M. Polyamines induce adaptive responses in water deficit stressed cucumber roots. Journal of Plant Research, Kurashiki, v. 127, p. 151-158, 2014.

ORO, P.; VOLKWEIS, R. C.; NEIVERTH, W.; DRANSKI, J. A. L.; MALAVASI, U. C.; MALAVASI, M. M. Aplicação de regulador vegetal na aclimatação de mudas de Cariniana estrellensi. Cultivando o Saber, Cascavel, v. 5, n. 4, p. 103-112, 2012.

RITCHIE, G. A.; LANDIS, T. D.; DUMROESE, R. K.; HAASE, D. L. Assessing Plant Quality. In: LANDIS, T.D.; DUMROESE, R. K.; HAASE, D. L. (Eds.). The container tree nursery manual: seedling processing, storage, and outplanting. v. 7. Washington: Department of Agriculture Forest Service, 2010, p.19-81.

TAIZ, L.; ZEIGER, E. Plant Physiology and Development, sixth ed. Sinauer Associates, Sunderland, 2017.

URBANETZ, C., LEHN, C. R., SALIS, S. M., BUENO, M. L., ALVES, F. M. Composição e distribuição de espécies arbóreas em gradiente altitudinal, morraria do Urucum, Brasil. Oecologia Australis, Rio de Janeiro, v. 16, n. 4, p. 859-877, 2012.

VIEIRA, E. L; SOUZA, G. L; SANTOS, A. R; SILVA, J. S. Manual de fisiologia vegetal. São Luis: EDUFMA, 2010, 230p.

VOLKWEIS, R. C.; DRANSKI, J. A. L.; ORO, P.; MALAVASI, U. C.; MALAVASI, M. M. Efeito da tigmomorfogênese na morfometria de mudas de Maytenus ilicifolia (Schrad.) Planch. Ciência Florestal, Santa Maria, v. 24, n. 2, p. 339-342, 2014.

WILNER, J. Relative and absolute electrolyte conductance tests for frost hardiness of apple varieties. Canadian Journal of Plant Science, Ottawa, v. 40, p. 630-637, 1960.

ZAS, R.; BJORKLUND, N.; NORDLANDER, G.; CENDAN, C.; HELLQVIST, C.; SAMPEDRO, L. Exploiting jasmonate-induced responses for field protection of conifer seedlings against a major forest pest, Hylobius abieti. Forest Ecology and Management, Mexico, v. 313, n. 1, p. 212-223, 2014.

ZHU, X.; CHEN, J.; XIE, Z.; GAO, J.; REN, G.; GAO, S.; ZHOU, X.; KUAI, B. Jasmonic acid promotes degreening via MYC2/3/4- and ANAC019/055/072-mediated regulation of major chlorophyll catabolic genes. The Plant Journal, Oxford, v. 84, p. 597-610, 2015. 